\title{
PEMANFAATAN HUTAN KOTA DI WILAYAH JAKARTA TIMUR SEBAGAI KAWASAN REKREASI MASYARAKAT KOTA
}

\section{Urban Forest Utilization in East Jakarta for City Dwellers Recreation Area}

\section{Nike Dyah Permata \\ Mahasiswa Sekolah Pascasarjana IPB, Program Studi Arsitektur Lanskap Email : nike.dyah@ymail.com \\ Syartinilia \\ Staf Pengajar Departemen Arsitektur Lanskap, Fakultas Pertanian IPB}

\section{Aris Munandar}

Pengajar Departemen Arsitektur

Lanskap, Fakultas Pertanian IPB

\section{ABSTRACT}

Urban forests have benefits for urban recreational activities for dwellers and also the identity of a city. East Jakarta is one of the areas in DKI Jakarta that has the largest number of urban forests currently. Urban forest has not been utilized optimally by the dwellers. For recreation activities, urban forest utilization for recreation activities become an interesting to observe. Therefore, the objective of this study was to analyzed urban forests utilization by the dwellers,especially in East Jakarta. Observation was done through interview and then was analyzed using linier regression. Urban forests coverage area were determined through buffer analysis using the level of urban forest accessibility by walk. The results shown that $85 \%$ urban forests was visited by dwellers came from inside urban forest coverage area. Recreational activities recorded while observed in the urban forest were exercising, sightseeing, picnic, camping, etc. The number of object in each urban forest was positively correlated with the high proportion of visitor from outside the urban forest coverage area.

Keywords: Urban Recreation, Urban Forest Utilization, Recreational Activities, East Jakarta, Urban Forest, Accessibility.

\section{PENDAHULUAN}

Pemanfaatan ruang terbuka hijau seperti hutan kota sangatlah penting, terutama bagi lingkungan perkotaan dengan jumlah penduduk yang padat. Hutan kota dapat meningkatkan kualitas lingkungan perkotaan sekaligus sebagai identitas suatu kota. Berbagai manfaat hutan kota dapat dirasakan baik secara aspek ekologi, sosial, dan budaya. Salah satu manfaat sosial yang bisa dirasakan oleh masyarakat diantaranya adalah hutan kota dapat berfungsi sebagai kawasan rekreasi, sarana pembelajaran untuk anakanak, sebagai tempat untuk mengisi waktu luang, dan dapat mengurangi stress (Lestari et al. 2005). Hutan kota merupakan salah satu bagian dari lingkungan yang juga berfungsi sebagai ruang rekreasi publik, khususnya untuk masyarakat yang tinggal di wilayah perkotaan (Font dan Tribe 2000). Sebagian besar kawasan rekreasi yang berada di perkotaan umumnya cukup minim pepohonan, terutama untuk tipe outdoor recreation. Oleh karena itu hutan kota merupakan salah satu sarana outdoor recreation yang dapat dimanfaatkan oleh masyarakat perkotaan untuk melakukan aktivitas rekreasi mereka.

Keberadaan hutan kota selain sebagai kawasan rekreasi untuk masyarakat kemudian dijadikan sebagai suatu identitas kota oleh pemerintah Jakarta Timur. Jakarta Timur merupakan salah satu wilayah dengan jumlah hutan kota terbanyak di DKI Jakarta, yaitu sebanyak 15 hutan kota $(149,76$ ha). Beberapa hutan kota yang berada di wilayah Jakarta Timur diantaranya adalah Hutan Kota Komplek Lanud Halim Perdana Kusuma, Hutan Kota Komplek Kopassus Cijantung, Hutan Kota PT JIEP Pulo Gadung, Hutan Kota Mabes TNI Cilangkap, Hutan Kota Buperta Cibubur, Hutan Kota Situ Rawa
Dongkal, Hutan Kota Dukuh, Hutan Kota Ujung Menteng, Hutan Kota Munjul, Hutan Kota Setu, Hutan Kota Pondok Ranggon, Hutan Kota Cilangkap, Hutan Kota Cipayung, Hutan Kota Ciracas, dan Hutan Kota Pulo Gebang (BPS 2017).

Jumlah penduduk berperan penting sebagai indikator ketersediaan hutan kota untuk kota yang sedang berkembang. Tingginya jumlah penduduk di Jakarta Timur berpengaruh juga terhadap kebutuhan hutan kota, karena hutan kota akan memberikan kenyamanan bagi masyarakat sekitarnya. Pemerintah Jakarta Timur telah berupaya untuk meningkatkan kualitas hutan kota. Upaya yang telah dilakukan oleh pemerintah diantaranya adalah penambahan pohon, objek, serta sarana dan prasarana di dalam hutan kota (Firdaus 2015). Beberapa hutan kota di Jakarta Timur sudah dilengkapi dengan berbagai macam sarana dan prasarana guna menunjang aktivitas pengunjung. Namun beberapa hutan kota masih sepi pengunjung, sehingga dibiarkan begitu saja oleh masyarakat. Oleh karena itu perlu adanya kajian mengenai bagaimana pemanfaatan hutan kota sebagai kawasan rekreasi oleh masyarakat. Tujuan dari penelitian ini adalah untuk mengetahui sejauh mana hutan kota di Jakarta Timur telah dimanfaatkan oleh masyarakat untuk kegiatan rekreasi.

\section{METODOLOGI}

\section{Waktu dan Lokasi Penelitian}

Waktu penelitian dilakukan pada bulan Juli sampai November 2017. Lokasi kajian dilakukan pada hutan kota yang tersebar di wilayah Jakarta Timur dengan luas wilayah 1877500 ha. Secara astronomis wilayah Jakarta Timur terletak pada koordinat $106^{\circ} 49^{\prime}$ 35" BT dan $610^{\prime} 37^{\prime \prime}$ LS. Luas wilayah Jakarta timur ialah 
118,03 ha dengan jumlah penduduk paling banyak dibandingkan dengan wilayah administratif DKI Jakarta lainnya, yaitu 2.843.816 jiwa (BPS 2015). Hutan kota yang dijadikan sebagai sample penelitian ini dipilih berdasarkan pada Surat Keputusan (SK) bahwa hutan kota tersebut telah ditetapkan sebagai kawasan hutan kota di wilayah tersebut. Hutan kota yang menjadi lokasi penelitian terdiri dari 7 hutan kota (59,76 ha), diantaranya adalah Hutan Kota Komplek Lanud Halim Perdana Kusuma (3,50 ha), Hutan Kota Komplek Kopassus Cijantung (1,75 ha), Hutan Kota PT JIEP Pulo Gadung $(8,90$ ha), Hutan Kota Mabes TNI Cilangkap (14,43 ha), Hutan Kota Buperta Cibubur (27,32 ha), Hutan Kota Situ Rawa Dongkal (3,28 ha), dan Hutan Kota Dukuh (0,50 ha) (Gambar 1). Fokus penelitian ini adalah untuk melihat penggunaan hutan kota sebagai kawasan rekreasi oleh masyarakat yang tinggal di sekitar hutan kota tersebut.

\section{Alat dan Bahan}

Alat yang digunakan pada penelitian adalah kamera digital, Global Positioning System (GPS), google earth, ArcGIS 10.4, dan IBM SPSS Statistics 24. Sementara bahan yang diperlukan dalam penelitian ini adalah peta batas wilayah hutan kota dari hasil digitasi image yang dilakukan di google earth (https:// earth.google.com) dan peta batas wilayah administrasi provinsi DKI Jakarta.

\section{Metode Penentuan Sampel Pengunjung Hutan Kota}

Pengambilan sampel pengunjung hutan kota ditujukan untuk mengetahui asal kelurahan pengunjung serta aktivitas yang mereka lakukan selama berada di dalam hutan kota tersebut. Metode pengambilan sampel pengunjung dilakukan dengan pendekatan non-probability sampling melalui metode convenience sampling. Jumlah populasi pada penelitian ini tidak diketahui secara pasti, oleh karena itu berdasarkan pada Roscoe (Sugiyono, 2013) jumlah minimal sampel yang dibutuhkan adalah 30 sampel. Tiap hutan kota diambil sampel pengunjung hingga mewakili 5 kelurahan, sehingga diperoleh sebanyak 48 pengunjung selama pengamatan berlangsung.

\section{Tahapan Penelitian}

Pemanfaatan hutan kota oleh masyarakat pada penelitian ini dilihat dari banyaknya jumlah asal pengunjung hutan kota. Untuk memperoleh hal tersebut maka dilakukanlah beberapa tahap penelitian diantaranya adalah: 1) menganalisis cakupan buffer hutan kota dilakukan guna mengetahui area kelurahan yang berhasil dicakup oleh hutan kota tersebut, 2) menganalisis asal pengunjung hutan kota, 3) menganalisis hubungan antara objek hutan kota dengan jumlah asal pengunjung.

\section{Analisis Cakupan Buffer Hutan Kota}

Pada tahap ini dilakukan buffer analysis dengan menggunakan software ArcGIS 10.4. Buffer analysis merupakan metode analisis yang membentuk zona

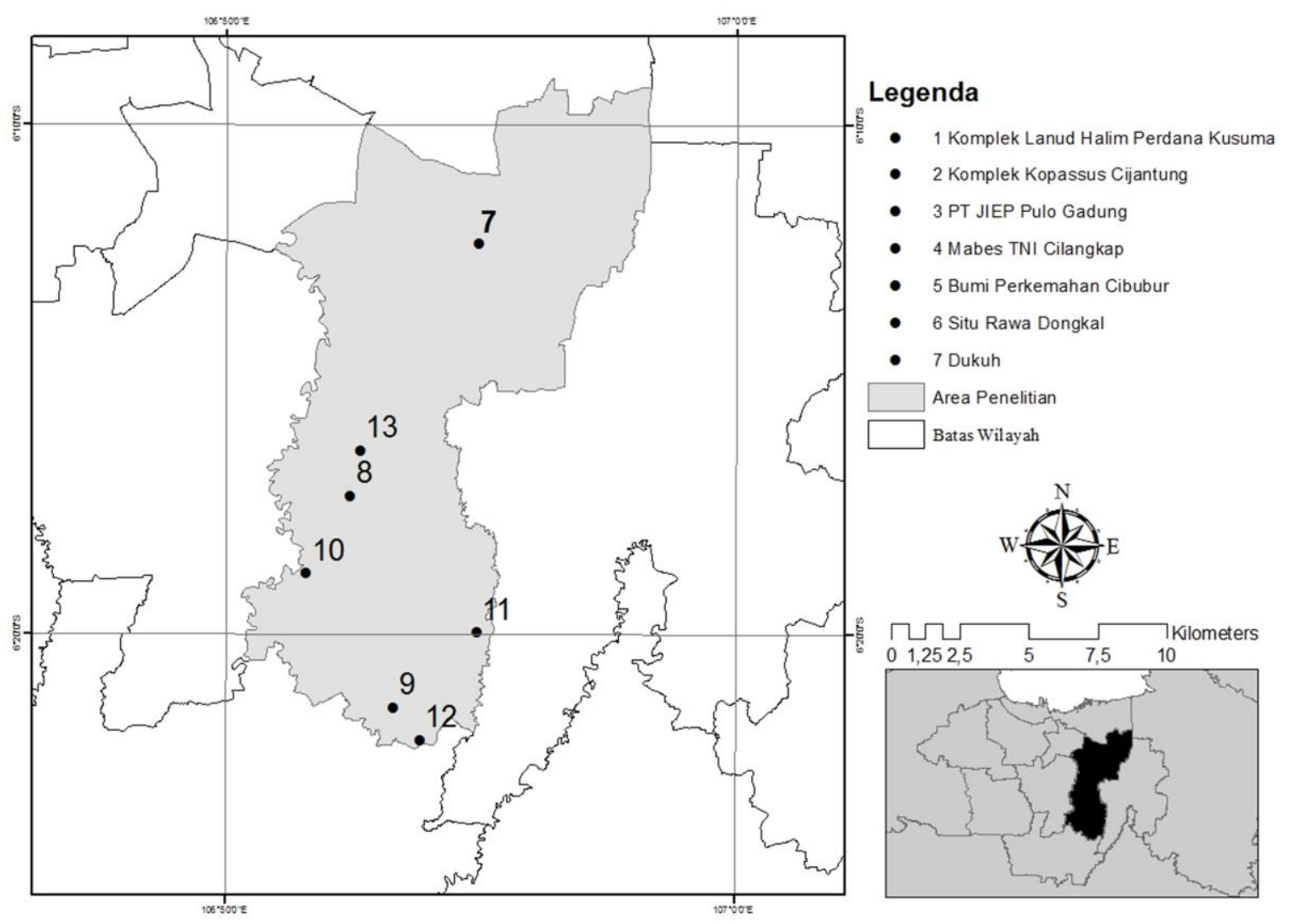

Gambar 1 Sebaran Lokasi Penelitian Hutan Kota 
dari suatu jarak tertentu di sekitar entitas fisik telah terdefenisi (Pramudia 2008). Buffer digunakan untuk mengetahui sejauh mana hutan kota dapat mencakup area kelurahan di sekitarnya. Buffer untuk tiap luasan hutan kota berbeda tergantung pada luas masingmasing hutan kota, yang mengacu pada ketentuan radius buffer hutan kota untuk dijangkau dengan berjalan kaki (Van Harzele 2003) dan telah modivikasi (Tabel 1). Informasi yang dibutuhkan pada analisis ini adalah peta sebaran lokasi penelitian hutan kota dan batas wilayah hutan kota, yang kemudian di-overlay dari kedua peta tersebut.

\section{Analisis Asal Pengunjung}

Tahapan selanjutnya dilakukan teknik wawancara kepada beberapa pengunjung hutan kota guna mengetahui asal pengunjung dan aktivitas yang dilakukan selama berada di dalam hutan kota. Selanjutnya dilakukan analisis data secara deskriptif. Asal pengunjung akan dibagi menjadi dua, yaitu pengunjung di dalam cakupan buffer hutan kota dan pengunjung di luar cakupan buffer hutan kota. Hal ini dilakukan untuk mengetahui persentase jumlah asal pengunjung yang termasuk di dalam cakupan buffer hutan kota dan asal pengunjung di luar cakupan buffer hutan kota dalam memanfaatkan hutan kota tersebut.

\section{Analisis Hubungan antara Objek Hutan Kota dengan Asal Pengunjung}

Tahap terakhir dari penelitian ini adalah dengan menggunakan analisis korelasi antara objek yang terdapat di hutan kota dan jumlah pengunjung dilakukan dengan menggunakan persamaan linier regresi. Analisis dilakukan dengan IBM SPSS Statistics 24. Analisis Metode statistik tersebut digunakan guna menguji hubungan sebab akibat antara variabel bebas (X) terhadap variabel tak bebas (Y) (Filqisthi 2016). Objek hutan kota merupakan variabel bebas, sedangkan jumlah asal kelurahan pengunjung sebagai variabel tak bebas. Hipotesis yang digunakan adalah: H0 : Jumlah objek hutan kota tidak berpengaruh nyata terhadap jumlah pengunjung,

H1 : Jumlah objek hutan kota berpengaruh nyata terhadai jumlah pengunjung.

\section{HASIL DAN PEMBAHASAN}

\section{Kondisi Umum Lokasi Penelitian}

Hutan kota di wilayah Jakarta Timur yang termasuk dalam kajian penelitian ini terdiri dari 7 hutan kota dengan luas wilayah yang berbeda-beda (Tabel 2). Tiap-tiap hutan kota memiliki variasi luas yang berbeda, mulai dari 0,50 - 27,32 ha. Hutan kota di Jakarta Timur telah dapat diakses dengan menggunakan berbagai sarana transportasi umum, seperti busway, bus, angkutan kota, dan transportasi online seperti grab, gojek, dan uber. Berdasarkan hasil pengamatan jenis tanaman yang terdapat di dalam
Tabel 1 Luas Area dan Radius Buffer Hutan Kota

\begin{tabular}{ccc}
\hline No & Luas Hutan Kota (ha) & $\begin{array}{c}\text { Radius Buffer } \\
\text { (km) }\end{array}$ \\
\hline 1 & $>20$ & $>4$ \\
\hline 2 & 20 & 4,0 \\
\hline 3 & 18 & 3,5 \\
\hline 4 & 16 & 3,0 \\
\hline 5 & 14 & 2,5 \\
\hline 6 & 12 & 2,0 \\
\hline 7 & 10 & 1,5 \\
\hline 8 & 8 & 1,0 \\
\hline 9 & 2 & 0,5 \\
\hline 10 & $<2$ & 0,3 \\
\hline
\end{tabular}

Tabel 2 Nama dan Luas Hutan Kota di Jakarta Timur

\begin{tabular}{ll}
\hline Hutan Kota & $\begin{array}{l}\text { Luas Hutan Kota } \\
\text { (ha) }\end{array}$ \\
\hline $\begin{array}{l}\text { Komplek Lanud Halim } \\
\text { Perdana Kusuma }\end{array}$ & 3,50 \\
\hline Komplek Kopassus Cijantung & 1,75 \\
\hline PT JIEP Pulo Gadung & 8,90 \\
\hline Mabes TNI Cilangkap & 14,43 \\
\hline Buperta Cibubur & 27,32 \\
\hline Situ Rawa Dongkal & 3,28 \\
\hline Dukuh & 0,50 \\
\hline
\end{tabular}

hutan kota cukup bervariasi, diantaraya adalah akasia (Acacia crassicarpa), kenari (Canarium littorale), dadap merah (Erythrina crista-galli), melinjo (Gnetum gnemon), bungur (Lagerstroemia speciosa), lamtoro (Leucaena leucocephala), glodongan tiang (Polyalthia longifolia), angsana (Pterocarpus indicus), mahoni daun besar (Swietenia macrophylla), mahoni daun kecil (Swietenia mahagoni), trembesi (Samanea saman), sengon (Paraserianthes falcataria), saga (Adenanthera pavonina), ketapang (Terminalia catapa), petai cina (Leucaena leucocephala), bambu hijau (Bambusa tuldoides), buni (Antidesma bunius), bunga kupu-kupu (Bauhinia purpurea), kelapa (Cocos nucifera), karet (Hevea brasiliensis), melira, bungur (Lagerstroemia speciosa), tanjung (Mimomosops elengi), pinus (Pinus merkusii), glodogan tiang (Polyalthia longifolia), salam (Syzygium polyanthum), jati (Tectona grandis), kirai payung (Filicium defisien), pala manis (Myristica fragrans), lamtoro (Leucaena leucocephala), nyamplung (Calophyllum Inaphyllum), waru (Hibiscus tiliaceus), matoa (Pometia pinnata), kecapi (Sandoricum koetjape), pule (Alstonia scholaris), asam (Pithecellobium dulce), tanjung (Mimomosops elengi), johar, lamtoro (Leucaena leucocephala), angsana (Pterocarpus indicus), flamboyan (Delonix regia), dan kayu manis (Cinnamomum verum). 
Hutan kota sebagai kawasan rekreasi menawarkan beberapa jenis objek atau atraksi guna menarik minat pengunjung (Gunn 1993). Beberapa hutan kota yang tersebar di wilayah Jakarta Timur telah dilengkapi dengan beragam objek oleh pengelola hutan kota (Tabel 3). Hal tersebut dilakukan guna menarik minat masyarakat yang tinggal di sekitar hutan kota untuk berkunjung ke hutan kota. Hutan Kota Bumi Perkemaan Cibubur yang berada di Kelurahan Cibubur merupakan hutan kota terluas di Jakarta Timur (27,32 ha) sekaligus merupakan hutan kota yang telah difungsikan sebagai kawasan rekreasi untuk masyarakat sekitar. Objek yang terdapat di dalam hutan kota tersebut pun telah disesuaikan fungsinya untuk memenuhi kebutuhan dan aktifitas pengunjung. Hutan Kota Bumi Perkemaan Cibubur merupakan hutan kota dengan jumlah objek terbanyak di Jakarta Timur (3 objek alami dan 4 objek buatan). Namun, beberapa hutan kota pula masih minim objek seperti Hutan Kota Komplek Lanud Halim Perdana Kusuma (1 objek buatan), Hutan Kota Komplek Kopassus Cijantung (1 objek buatan), dan Hutan Kota
Situ Rawa Dongkal (1 objek alami). Selain itu Hutan Kota PT JIEP Pulo Gadung, Hutan Kota Mabes TNI Cilangkap, dan Hutan Kota Dukuh tidak terdapat objek, baik alami maupun buatan, yang dapat menarik minat masyarakat sekitar untuk berkunjung.

\section{Cakupan Buffer Hutan Kota}

Berdasarkan pada hasil analisis dengan menggunakan buffer analysis meggunakan standar yang digunakan oleh Van Herzele, diperoleh bahwa hutan kota wilayah Jakarta Timur dapat mencakup beberapa jumlah kelurahan tergantung pada luas area hutan kota tersebut (Gambar 2). Pada Tabel 4 diketahui bahwa hanya Hutan Kota Mabes TNI Cilangkap (18 kelurahan) dan Hutan Kota Buperta Cibubur (25 kelurahan) yang dapat mencakup lebih dari 10 kelurahan. Sejumlah 5 hutan kota mencakup kurang dari 10 kelurahan, yaitu Hutan Kota Komplek Lanud Halim Perdana Kusuma, Hutan Kota Komplek Kopassus Cijantung, Hutan Kota PT JIEP Pulo Gadung, Hutan Kota Situ Rawa Donsgkal, dan Hutan Kota Dukuh.

Tabel 3 Objek Pada Masing-Masing Hutan Kota

\begin{tabular}{|c|c|c|c|}
\hline \multirow{2}{*}{ Hutan Kota } & \multicolumn{2}{|l|}{ Objek } & \multirow{2}{*}{ Tota } \\
\hline & Alami & Buatan & \\
\hline $\begin{array}{l}\text { Komplek Lanud Halim Perdana } \\
\text { Kusuma }\end{array}$ & - & Kolam pemancingan & 1 \\
\hline Komplek Kopassus Cijantung & - & Jogging track, Robot & 2 \\
\hline PT JIEP Pulo Gadung & - & - & - \\
\hline Mabes TNI Cilangkap & - & - & - \\
\hline Buperta Cibubur & $\begin{array}{l}\text { Hutan pinus, Danau, } \\
\text { Camping ground }\end{array}$ & $\begin{array}{l}\text { Taman rekreasi, } \\
\text { Outbond, Lapangan } \\
\text { olahraga, Kolam } \\
\text { renang, aula serba } \\
\text { guna }\end{array}$ & 8 \\
\hline Situ Rawa Dongkal & Danau & - & 1 \\
\hline Dukuh & - & Jogging track & 1 \\
\hline
\end{tabular}

Tabel 4 Luas Area Cakupan Hutan Kota

\begin{tabular}{llll}
\hline Hutan Kota & $\begin{array}{l}\text { Radius } \\
\text { Buffer }(\mathbf{k m})\end{array}$ & $\begin{array}{l}\text { Luas Area Cakupan } \\
\text { Buffer (ha) }\end{array}$ & $\begin{array}{l}\text { Jumlah Cakupan } \\
\text { Kelurahan }\end{array}$ \\
\hline Komplek Lanud Halim Perdana Kusuma & 0,5 & 200,50 & 5 \\
\hline Komplek Kopassus Cijantung & 0,5 & 111,35 & 3 \\
\hline PT JIEP Pulo Gadung & 1,0 & 475,05 & 6 \\
\hline Mabes TNI Cilangkap & 2,5 & $2.372,59$ & 18 \\
\hline Buperta Cibubur & 4,0 & $6.312,09$ & 25 \\
\hline Situ Rawa Dongkal & 0,5 & 157,64 & 2 \\
\hline Dukuh & 0,3 & 38,20 & 2 \\
\hline
\end{tabular}




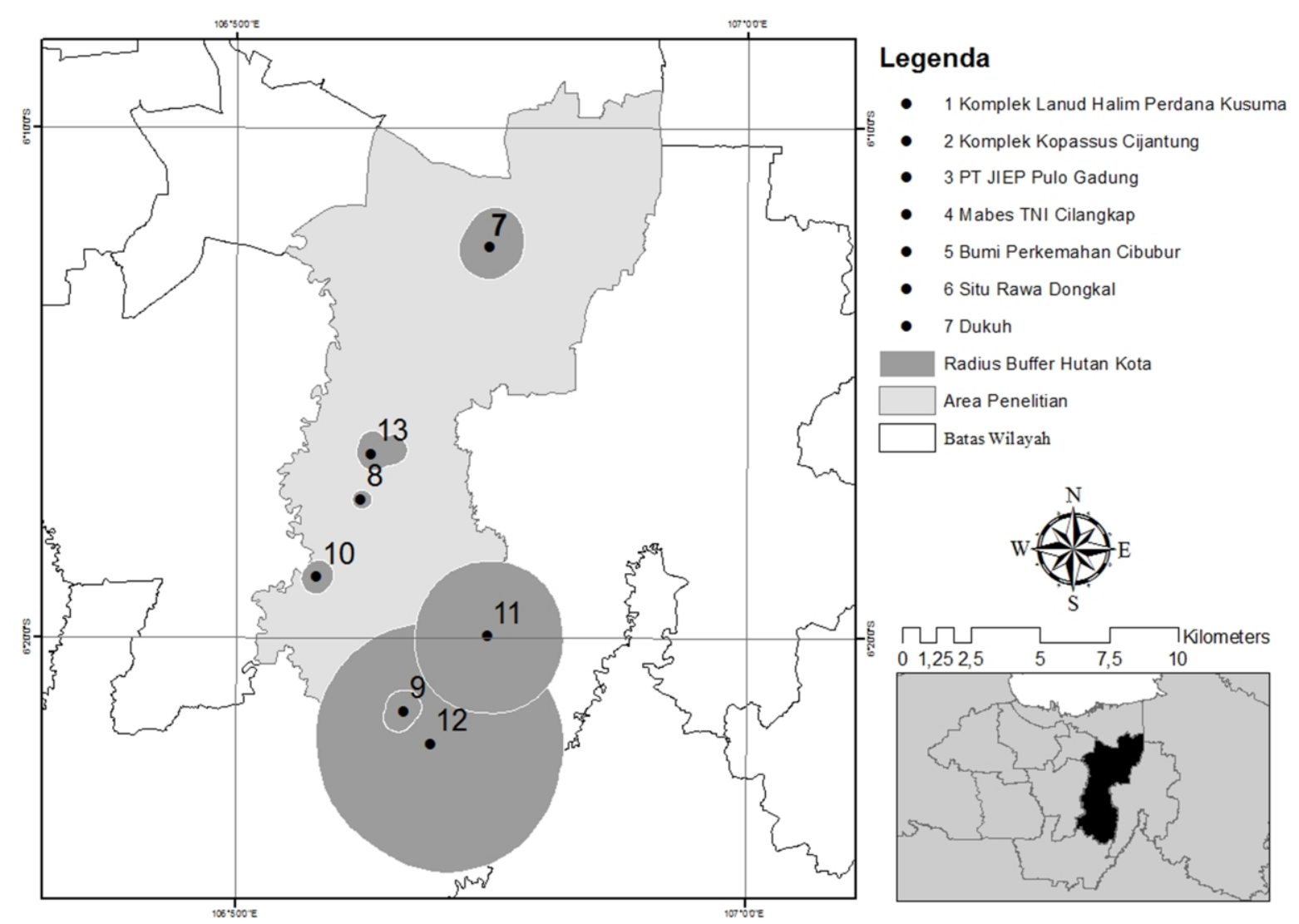

Gambar 2 Radius Buffer Hutan Kota

Hutan kota di wilayah Jakarta Timur dengan total luas area cakupan buffer hutan kota paling banyak adalah Hutan Kota Buperta Cibubur, yaitu 6.312,09 ha (25 kelurahan) dan hutan kota dengan luas area cakupan buffer hutan kota terkecil adalah Hutan Kota Dukuh yaitu 38,20 ha (2 kelurahan) (Gambar 3). Kelurahan yang termasuk ke dalam cakupan buffer Hutan Kota Buperta Cibubur adalah Kelurahan Pekeyon, Kelurahan Kalisari, Kelurahan Ciangsana, Kelurahan Nagrak, Kelurahan Cikeas Udik, Kelurahan Cububur, Kelurahan Kelapa Dua Wetan, Kelurahan Ciracas, Kelurahan Pondok Ranggon, Kelurahan Cilangkap, Kelurahan Munjul, Kelurahan Cipayung, Kelurahan Cilangkap, Kelurahan Bojong Nangka, Kelurahan Leuwinanggung, Kelurahan Tapos, Kelurahan Jatijajar, Kelurahan Sukamaju Baru, Kelurahan Sukatani, Kelurahan Curug, Kelurahan Harjamukti, Kelurahan Cisalak, Kelurahan Cisalak Pasar, Kelurahan Mekarsari, dan Kelurahan Tugu. Terdapat dua hutan kota dengan jumlah cakupan kelurahan paling sedikit adalah Hutan Kota Situ Rawa Dongkal dan Hutan Kota Dukuh. Kelurahan yang termasuk dalam cakupan buffer Hutan Kota Situ Rawa Dongkal adalah Kelurahan Pekeyon dan Kelurahan Cububur. Kelurahan yang termasuk dalam cakupan buffer Hutan Kota Dukuh adalah Kelurahan Batu Ampar dan Kelurahan Kampung Tengah.

\section{Asal Pengunjung Hutan Kota}

Sebanyak 85\% hutan kota dikunjungi oleh masyarakat yang berasal dari dalam kawasan cakupan buffer hutan kota dan $15 \%$ hutan kota dikunjungi oleh masyarakat yang berasal dari luar kawasan cakupan buffer hutan kota (Gambar 4). Hasil pada grafik di Gambar 5 menunjukkan bahwa umumnya pegunjung yang berkunjung ke masing-masing hutan kota berasal dari kelurahan dalam cakupan buffer hutan kota. Hutan Kota Dukuh, Hutan Kota Situ Rawa Dongkal, dan Hutan Kota Komplek Lanud Halim Perdana Kusuma merupakan hutan kota yang dikunjungi oleh masyarakat yang tinggal di sekitar hutan kota, atau masyarakat yang tinggal di kelurahan yang termasuk dalam kawasan cakupan buffer hutan kota. Hutan Kota Bumi Perkemahan Cibubur (80\% pengunjung dalam cakupan buffer dan 20\% pengunjung luar cakupan buffer), Hutan Kota PT JIEP Pulo Gadung (40\% pengunjung dalam cakupan buffer dan $60 \%$ pengunjung luar cakupan buffer), dan Hutan Kota Komplek Kopassus Cijantung (60\% pengunjung dalam cakupan buffer dan $40 \%$ pengunjung luar cakupan buffer), merupakan hutan kota yang dikunjungi oleh masyarakat yang tinggal di kelurahan yang termasuk dalam kawasan cakupan buffer hutan kota dan di luar cakupan buffer hutan kota.

Hubungan Objek Hutan Kota dan Jumlah Pengunjung 


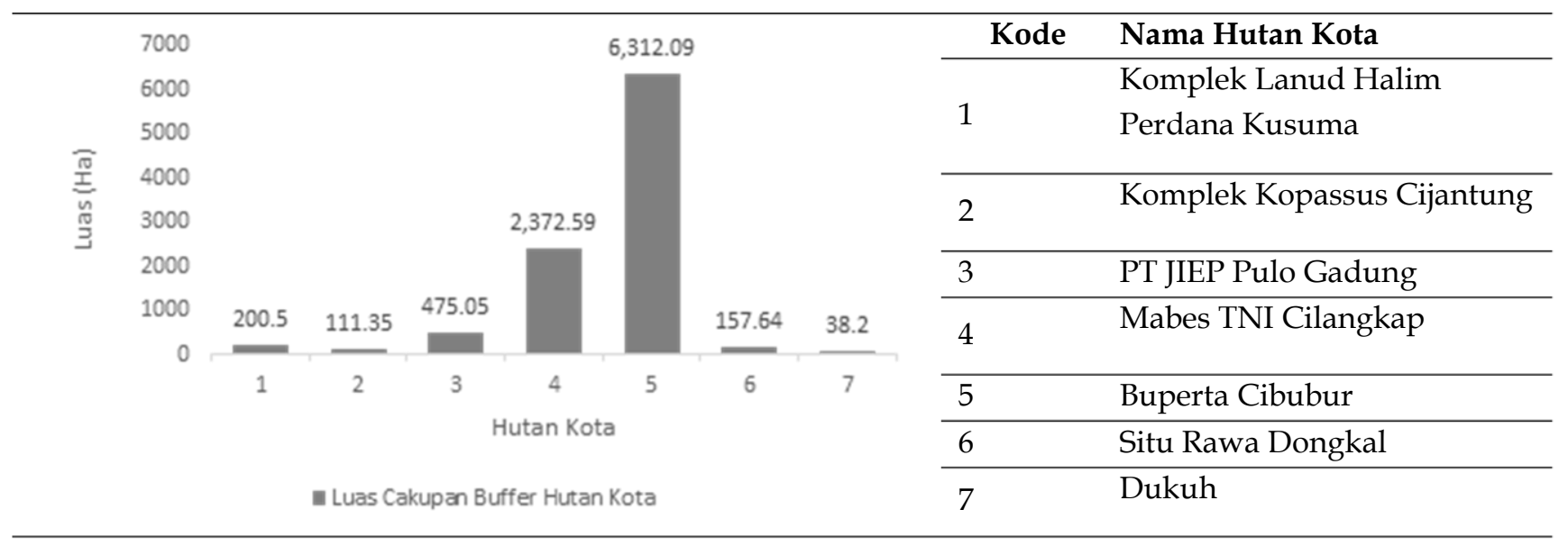

Gambar 3 Luas Area Cakupan Hutan Kota

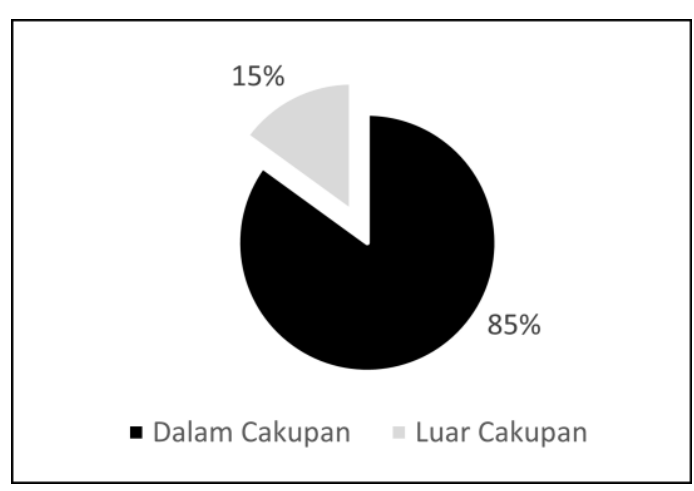

Gambar 4 Persentasi Jumlah Asal Kelurahan Pengunjung

Uji regresi linier sederhana dilakukan untuk melihat hubungan antara jumlah pengunjung hutan kota dengan jumlah objek yang terdapat di hutan kota. Hipotesa dari korelasi tersebut adalah hutan kota dengan jumlah objek yang memenuhi aktivitas pengunjung akan semakin ramai dan banyak dikunjungi oleh pengunjung. Hasil uji regresi linier sederhana antara jumlah objek hutan kota dengan jumlah asal kelurahan pengunjung adalah berhubungan positif $\left(R^{2}=0,962\right)$. Dengan nilai signifikansi 0,000 berarti terdapat hubungan yang signifikan antara jumlah objek hutan kota dengan jumlah pengunjung karena nilai signifikansinya $\leq 0,05$.

\section{Pembahasan}

Berdasarkan hasil analisis dan wawancara dengan pengunjung hutan kota, diperoleh bahwa sebanyak 85\% hutan kota di Jakarta Timur dikunjungi oleh masyarakat yang berasal dari dalam kawasan cakupan buffer hutan kota. Hal ini menunjukkan bahwa masyarakat lebih memilih untuk mengunjungi hutan kota yang berada dekat dengan mereka. Hal tersebut dikarenakan jarak yang dekat sekaligus kemudahan akses untuk menuju hutan kota, menjadi alasan sebagian besar pengunjung masih berasal dari dalam

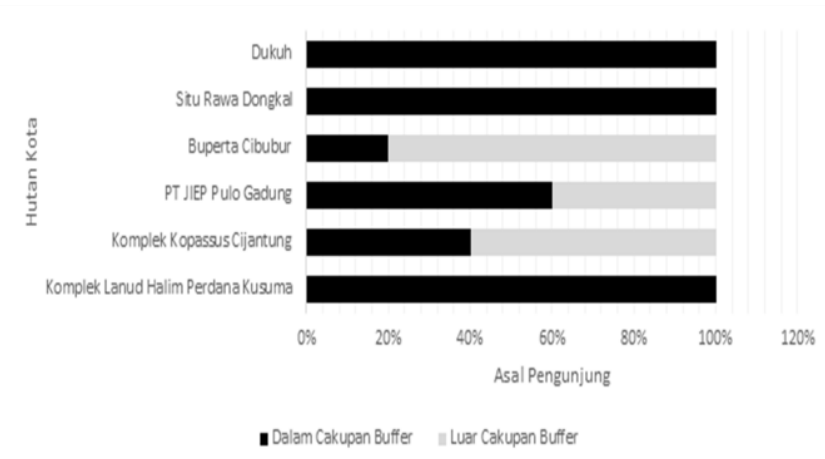

Gambar 5 Asal Kelurahan Pengunjung

kawasan cakupan buffer hutan kota. Menurut Van Herzele dan Wiedemann (2003), pengunjung hutan kota akan mencari lokasi yang mudah dijangkau dengan berjalan kaki, sehingga masyarakat akan memilih lokasi yang terdekat dengan mereka. Semakin dekat lokasi tujuan dengan masyarakat maka akan semakin mempermudah masyarakat untuk megunjungi hutan kota. Selain itu dekatnya jarak hutan kota dengan masyarakat membuat masyarakat tidak membutuhkan waktu yang lama untuk mencapai lokasi hutan kota tersebut (Tyrväinen et al J 2007). Semakin dekat dan semakin cepat masyarakat dapat mengakses hutan kota maka akan semakin menghemat waktu yang dibutuhkan masyarakat untuk untuk menuju ke hutan kota tersebut. Menurut Burton (1995) aksesibilitas merupakan salah satu faktor penting untuk memudahkan masyarakat mengakses hutan kota. Ketersediaan transportasi umum, seperti bus, angkutan kota, kereta, busway, dan transportasi online, serta jaringan jalan pula berperan penting untuk memudahkan masyarakat menuju hutan kota.

Hutan kota di Jakarta Timur manawarkan beragam jenis tanaman yang bervariasi dan struktur tanaman yang baik sebagai objek untuk menarik minat 
pengunjung. Hutan kota sebagai sebuah kawasan rekreasi akan dikatakan menarik jika terdapat objek yang membuat jumlah pengunjung meningkat. Objek atau atraksi akan selalu berkaitan erat dengan pengunjung dan merupakan kunci evaluasi keberhasilan suatu kawasan wisata. Menurut Wardianta (2006) suatu kawasan rekreasi dapat dikatakan berhasil apabila objek di dalam kawasan rekreasi tersebut berhasil menarik perhatian masyarakat untuk berkunjung. Hutan kota umumnya hanya akan menawarkan sekelompok pepohonan yang terdiri dari beberapa strata tanaman dan beragam jenis tanaman yang berbeda. Berbagai penelitian sebelumnya telah menemukan bahwa masyarakat lebih memilih untuk mengunjungi hutan kota dengan kondisi lanskap yang baik dan struktur yang terbuka (Edwards et al., 2012; Ribe, 1989). Selain beragam jenis tanaman hutan kota di Jakarta Timur pula menawarkan beberapa objek alami maupun buatan, seperti danau, kolam pemancingan, taman rekreasi, camping ground, kolam renang, dan robot. Menurut Fyall et al (2003) objek yang dapat menarik minat masyarakat untuk berkunjung diantaranya adalah berupa infrastruktur, akomodasi, transportasi, atraksi, pedagang, sarana dan prasarana, aktivitas, dan layanan penunjang untuk pengunjung, seperti ATM, telekomunikasi, dan lain sebagainya. Bagi sebagian besar pengunjung, objek atau atraksi yang ditawarkan oleh pengelola hutan kota merupakan hal yang membuat mereka tertarik untuk mengunjungi hutan kota tersebut. Menurut Henderson (Font dan Tribe 2000) umumnya pengunjung tertarik untuk mengunjungi suatu kawasan wisata karena atraksi yang ditawarkan. Bagi sebagian pengunjung atraksi merupakan salah satu sarana atau kesempatan untuk berinteraksi dengan alam. Di dalam hutan kota tersebut pengunjung dapat mengetahui beragam varietas jenis tanaman, kehidupan satwa, menikmati suasana hutan, dan berjalan-jalan di dalam hutan kota tersebut.

Hasil regresi linier sederhana diperoleh bahwa hubungan antara jumlah objek hutan kota dengan jumlah asal kelurahan pengunjung berhubungan positif $\left(R^{2}=0,962\right)$. Hasil analisis korelasi tersebut menunjukkan bahwa jumlah objek yang terdapat di hutan kota berpengaruh terhadap banyaknya jumlah pengujung yang yang berkunjung ke hutan kota. Sehingga dapat disimpulkan bahwa terdapat hubungan yang sangat kuat dan bersifat postif serta signifikan antara jumlah objek hutan kota di wilayah Jakarta Timur dengan jumlah pengunjung.

Hutan Kota Komplek Kopassus Cijantung, Hutan Kota Buperta Cibubur, dan Hutan Kota PT JIEP Pulo Gadung merupakan hutan kota yang dikunjungi oleh pengunjung yang berasal dari luar area cakupan buffer hutan kota. Hal tersebut karena Hutan Kota Komplek Kopassus Cijantung dan Hutan Kota Buperta menawarkan beragam objek serta sarana dan prasarana yang dapat dinikmati oleh pengunjung. Menurut Pendit (1994) hutan kota harus memiliki objek atau atraksi yang dapat menarik minat masyarakat untuk berkunjung. Dalam hal ini objek yang terdapat di dalam Hutan Kota Komplek Kopassus Cijantung dan Hutan Kota Buperta Cibubur sangat berperan sebagai segala sesuatu yang menarik dan memiliki nilai untuk dikunjungi. Beragam objek yang ditawarkan oleh pengelola hutan kota tersebut menarik minat masyarakat yang berasal jauh dari lokasi hutan kota berkunjung.

Hutan Kota Komplek Kopassus Cijantung dan Hutan kota Buperta Cibubur telah difungsikan sebagai kawasan rekreasi untuk masyarakat, sehingga sarana dan prasarana yang terdapat di dalam hutan kota telah disesuaikan dengan kebutuhan pengunjung. Sedangkan Hutan Kota PT JIEP Pulo Gadung masih difungsikan sebagai kawasan konservasi karena lokasinya yang berada di dalam kawasan industri. Hutan Kota Komplek Kopassus Cijantung awalnya merupakan kawasan yang tertutup untuk umum, yang kemudian dibuka untuk umum sebagai kawasan rekreasi. Hutan kota ini hanya dibuka pada akhir pekan dan ramai dikunjungi masyarakat untuk berakhir pekan. Secara umum fasilitas yang terdapat di dalam hutan kota ini telah disesuaikan dengan kebutuhan pengunjung, seperti toilet, gazebo, tempat sampah, dan lain sebagainya. Serta terdapat objek berupa robot yang sangat menarik minat anak-anak untuk menuju ke hutan kota tersebut. Selain Hutan Kota Komplek Kopassus Cijantung, Hutan Kota Buperta Cibubur pun telah difungsikan sebagai kawasan rekreasi untuk masyarakat. Hutan Kota Buperta Cibubur cukup banyak diminati oleh masyarakat untuk dikunjungi. Hal tersebut karena hutan kota ini terdapat berbagai macam objek yang dapat dinikmati oleh pengunjung. Pada Hutan Kota Buperta Cibubur menawarkan objek berupa lapangan olahraga, camping ground, danau, hutan pinus, taman rekreasi, kolam renang, dan aula serba guna. Objek merupakan faktor penting untuk menarik minat pengunjung, karena objek akan menawarkan atraksi yang dapat dinikmati oleh pengunjung (Hörnsten 2000). Hutan Kota Komplek Kopassus Cijantung dan Hutan Kota Buperta Cibubur telah menawarkan berbagai macam objek dan juga fasilitas yang dapat mendukung aktivitas pengunjung, sehingga banyak masyarakat memilih berakhir pekan ke dua hutan kota tersebut. Selain Hutan Kota Komplek Kopassus Cijantung dan Hutan Kota Buperta Cibubur yang dikunjungi oleh masyarakat dari luar area cakupan buffer hutan kota, Hutan Kota PT JIEP Pulo Gadung pun dikunjungi oleh masyarakat dari luar area cakupan buffer hutan kota. Hutan Kota PT JIEP merupakan hutan kota yang berada di kawasan industri yang tidak terdapat objek maupun fasilitas di dalamnya, namun dikunjungi oleh masyarakat dari luar area cakupan buffer hutan kota. Hal tersebut 
karena masyarakat yang berkunjung adalah para pekerja di kawasan industri JIEP yang berasal dari kelurahan di luar area cakupan buffer hutan kota.

Secara umum hutan kota telah dikunjungi oleh masyarakat dari dalam cakupan buffer hutan kota, hanya Hutan Kota Mabes TNI Cilangkap tidak terdapat pengunjung, baik dari dalam maupun luar cakupan buffer hutan kota. Hal tersebut karena Hutan Kota Mabes TNI Cilangkap tertutup untuk umum, sehingga masyarakat dilarang untuk memasuki kawasan tersebut. Hutan Kota Mabes TNI Cilangkap berada di dalam kawasan TNI sehingga dirasa akan mengganggu aktivitas para anggota TNI jika terdapat warga yang beraktivitas di dalam kawasan tersebut.

Saat ini penggunaan hutan kota sebagai kawasan rekreasi untuk masyarakat sangatlah penting, terutama untuk masyarakat yang tinggal di sekitar hutan kota dan merasakan manfaat langsung dari keberadaan hutan kota tersebut. Hutan kota dapat berfungsi sebagai sarana outdoor recreation bagi masyarakat kota sehingga mereka bisa berinteraksi dengan alam. Beragam jenis aktivitas dapat dilakukan oleh pengunjung selama berada di dalam hutan kota. Menurut Sarker dan Surry (1998) beberapa pengunjung dapat beristirahat di dalam hutan, menikmati suasana hutan, melihat dan berburu burung dan satwa, piknik, orientasi, outbond, studi lapang, fieldtrip, dan lain sebagainya. Menurut Hodge, melihat kehidupan satwa merupakan salah satu nilai lebih hutan sebagai kawasan rekreasi dan dapat dijadikan sebagai salah satu atraksi untuk menarik minat pengunjung (Font dan Tribe 2000). Masyarakat yang berkunjung ke hutan kota di Jakarta Timur umumnya melakukan beragam aktivitas, mulai dari aktivitas aktif maupun aktivitas pasif. Hutan Kota Bumi Perkemahan Cibubur merupakan hutan kota yang menawarkan beragam objek, diantaranya adalah camping ground, lapangan olahraga, sarana outbond, dan sebagainya, sehingga banyak aktivitas yang dilakukan oleh pengunjung. Aktivitas yang pengunjung lakukan selama berada di dalam Hutan Kota Bumi Perkemahan Cibubur, diantaranya adalah camping, melakukan kegiatan pramuka, atau kegiatan lain yang berkaitan dengan alam, berolahraga, bersepeda, menikmati suasana hutan, dan berekreasi. Hutan kota lainnya seperti Hutan Kota Komplek Kopassus Cijantung, Komplek Lanud Halim Perdana Kusuma, Hutan Kota Situ Rawa Dongkal, dan Hutan Kota Dukuh merupakan hutan kota dengan objek yang masih minim. Umumnya masyarakat yang berkunjung ke hutan kota tersebut di atas melakukan beberapa aktvitas, seperti memancing, berolahraga, berekreasi, dan menghabiskan akhir pekan bersama dengan keluarga. Sedangkan Hutan Kota PT JIEP Pulo Gadung merupakan hutan kota yang berada di kawasan industri, sehingga tidak terdapat objek selain sekumpulan pepohonan. Umumnya pengunjung Hutan Kota PT JIEP Pulo Gadung merupakan para pekerja industri yang beristirahat dan bersantai di sekitar kawasan hutan kota karena suasananya yang teduh.

\section{SIMPULAN}

Seluruh hutan kota yang tersebar di wilayah Jakarta Timur dapat diakses oleh masyarakat dengan menggunakan transportasi online dan angkutan umum. Secara umum hutan kota di Jakarta Timur telah dimanfaatkan oleh masyarakat di sekitar hutan kota. Hal ini terlihat dari hasil analisis bahwa 85\% pengunjung hutan kota berasal dari kelurahan yang termasuk dalam cakupan buffer hutan kota. Selain dimanfaatkan oleh masyarakat dari dalam cakupan buffer hutan kota, terdapat pula hutan kota yang dimanfaatkan oleh masyarakat yang berasal dari luar cakupan buffer hutan kota, diantaranya adalah Hutan Kota Komplek Kopassus Cijantung, Hutan Kota Buperta Cibubur, dan Hutan Kota PT JIEP Pulo Gadung. Hutan kota tersebut menawarkan berbagai macam objek serta sarana dan prasarana yang dapat dinikmati oleh pengunjung, sehingga menarik masyarakat untuk mengunjungi hutan kota tersebut. Hasil korelasi menunjukkan bahwa objek hutan kota berpengaruh terhadap jumlah asal kelurahan pengunjung yang berasal dari luar area cakupan buffer hutan kota.

\section{DAFTAR PUSTAKA}

Burton, R. 1995. Travel Geography. London: Pitman Publishing.

Edwards D, Jay M, Jensen F, Lucas B, Marzano M, Montagne C, Peace A, Weiss G. 2012. Public preferences for structural attributes of forests: towards a pan European perspective. Policy Econ. 19: 12-19.

Filqisthi, TA. 2016. Analisis Korelasi Karbon Tersimpan Dan Biodiversitas Tanaman Pada Lanskap Pekarangan Di Daerah Aliran Sungai Cisadane Jawa Barat [skripsi]. Bogor: Institut Pertnian Bogor.

Firdaus. 2015. Persepsi Masyarakat Terhadap Fungsi Hutan Kota Di Lingkungan Padat Penduduk, (Studi Kasus : Hutan Kota Dukuh Jakarta Timur) [skripsi]. Jakarta: UIN Syarif Hidayatullah.

Font X dan Tribe J. 2000. Forest Tourism and Recreation Case Studies in Environmental Management. London: CABI Publising.

Fyall A, Callod C, Edwards B. 2003. Relationship Marketing: The Challenge for Destinations. Annals of Tourism Research. 30(3): 644-659.

Gunn, CA. 1993. Tourism Planning Basics, Concepts, Cases third Edition. USA: Taylor and Francis.

Hörnsten, L. 2000. Outdoor recreation in Swedish forests Implications for society and forestry. Silvestria. 196.

Lestari, RA dan Jaya, INS. 2005. Penggunaan Teknologi Pengindraan Jauh Satelit dan SIG untuk Menentukan Luas Hutan Kota: (Studi Kasus Di 
doi : 10.29244/jli.2018.10.2.47-55

Kota Bogor, Jawa Barat). Manajemen Hutan Tropika. 9(2): $55-69$.

Pendit, INS. 1994. Ilmu Pariwisata Sebuah Pengantar Perdana. Jakarta: Pradnya Paramita.

Pramudia E. 2008. Evaluasi Potensi Obyek Wisata Aktual Di Kabupaten Agam Sumatera Barat Untuk Perencanaan Program Pengembangan [tesis]. Bogor: Institut Pertnian Bogor.

Ribe, RG. 1989. The aesthetics of forestry: what has empirical forest research taught us? Environmental Management. 13: 55-74.

Tyrväinen L, Mäkinen K, Schipperijn J. 2007. Tools For Mapping Social Values Of Urban Woodlands And Other Green Areas. Landscape and Urban Planning. 79(1): 5-19.

Sarker, R dan Surry, Y. 1998. Economic value of big game hunting: the case of moose hunting in Ontario. Journal of Forest Economics. 4: 29-60.

Sugiyono. 2013. Metode Penelitian Pendidikan, Pendekatan Kuantitatif, kualitatif, dan RED. Bandung: Alfabeta.

Van Herzele, A dan Wiedemann, T. 2003. A Monitoring Tool For The Provision Of Accessible And Attractive Urban Green Spaces. Landscape and Urban Planning. 63: 109-126.

Wardianta. 2006. Metode Penelitian Pariwisata. Yogyakarta: CV Andi Offset. 
